\title{
A Critical Discourse Analysis of The Los Angeles Times and Tehran Times on the Representation of Iran's Nuclear Program
}

\author{
Moussa Ahmadian \\ Department of English language and literature, Arak University, Arak, Iran \\ Elham Farahani (Corresponding author) \\ Department of English language and literature, Arak University, Arak, Iran
}

\begin{abstract}
This study aims to investigate how ideological differences manifest themselves in the discourse of The Los Angeles Times and Tehran Times dealing with Iran's nuclear program to have a wake-up call about the power of language in changing one's view about the events. After the critical analyses of six news reports based on van Dijk's (2000) framework, it was found that the two newspapers represent the same issues differently, according to their different ideologies by using two macro-strategies of positive self-presentation and negative other-presentation which are realized by other discursive strategies such as: lexicalization, presupposition, consensus, hyperbole, illegality and disclaimer. Some implications of the findings are suggested.
\end{abstract}

Index Terms - newspapers, critical discourse analysis, Iran's nuclear program, ideology

\section{INTRODUCTION}

News discourses play a crucial role in changing and even shaping people's points of view and opinions about the events, the people and the world around them. In newspapers, the events are not usually (re)presented as they are in reality, but are represented in a way that the newspapers intend them to be (Reah, 2002). The events, therefore, are not mirrored but they go through journalistic practices which involve linguistic recontextualization in language. Through this, one single reality may be represented differently in different newspapers with different attitudes and ideologies. In other words, the words are played with and different linguistic devices are used to influence the readers' view of the events. Fowler (1991) states that "news is not just a value-free reflection of facts. Anything that is said or written about the world is articulated from a particular ideological position" (p. 101).

On account of the ideological loading and meaning-making function of news, it should come as no surprise that many scholars have investigated news discourse within different socially committed frameworks. In their book Manufacturing Consent: The Political Economy of the Mass Media (1988), Herman and Chomsky introduced the Propaganda Model which "is concerned with exploring the relationship between ideology, communicative power and social class interests" and "offers an institutional critique of mass media behavior" (Klaehn and Mullen, 2010, p.217). Herman and Chomsky state that one of the major functions of media is their propaganda function. By propaganda, it is meant that "most of the news content is oriented toward social reproduction, i.e., the continuation of the capitalist class system, especially in its neoliberal form. This means that information is usually framed within the parameters of elite interests and certain topics and ideas tend to be excluded" (Pedro 2011, p.1865). In this model, five factors (the ownership, advertising, information sourcing, flak, and anti-communism) are introduced as filters through which information must pass in order to be considered news. Herman (1996) states that:

the dominant media are firmly imbedded in the market system. They are profit-seeking businesses, owned by very wealthy people (or other companies); they are funded largely by advertisers who are also profit-seeking entities, and who want their ads to appear in a supportive selling environment. The media are also dependent on government and major business firms as information sources, and both efficiency and political considerations, and frequently overlapping interests, cause a certain degree of solidarity to prevail among the government, major media, and other corporate businesses. (p.1)

There are many other theories about news representation such as Bennett's (1990) indexing theory which is concerned with how journalists index the voices in the news coverage and how political viewpoints which are against the policies of the government are likely to be ignored or marginalized in the mass media. Framing theory also refers to the fact that issues and events presented to the people are framed by the media and people's understanding of the events is dependent on this framing (Semetko and Valkenburg, 2000). According to Entman (1993), to frame means "to select some aspect of a perceived reality to make them more salient, thus promoting a particular problem definition, casual interpretation, moral evaluation, and/or treatment recommendation" (p. 52). Likewise, Shoemaker and Reese's (1996) the Hierarchy of Influences focuses on five layers of factors which influence the content and the process of news 
production: the individual journalists' background and personal and political beliefs, journalism daily work routines, the organizational imperatives, influences from the outside of media organization: "sources, advertisers, the political power of government, market structures, and technology", and ideology which is believed to shape and be shaped by news content (Hackett, 2006. p.4).

Mass media in general and newspapers in particular have also received the attention of many critical discourse analysis (CDA) practitioners to resist the power of newspapers in manipulating and influencing people's ideas in a way that is in favor of the elite of the society. CDA is concerned with discourse in forming and being formed by social political practices (Fairclough, 2001) and aims to raise the readers' consciousness of the power of language in changing the events and influencing the readers' views.

In the same vein, the present study uses a CDA framework to elucidate how Iran's nuclear program, as one of the major issues of great significance in the ongoing tensions between the U.S. and Iran and the one which among other events has received more media attention in Iran and America, is represented in The Los Angeles Times and Tehran Times focus. Thus, the main research question in this study is:

How ideological differences manifest themselves in the discourse of The Los Angeles Times and Tehran Times dealing with Iran's nuclear issues?

The article first gives a short background of Iran's nuclear program. Then, the framework and the data collection procedures used in this study are provided. Next, the CDA analysis section will bring examples of the major discursive strategies detected in the news reports on Iran's nuclear program based on Van Djik's (2000) model. Finally, some general conclusions and implications based on the results of the study will be discussed.

\section{IRAN’S NUCLEAR PROGRAM: A BACKGROUND}

Before Iran's Islamic Revolution in 1979, the United States supplied Tehran with a nuclear research reactor and a nuclear cooperation agreement between the two countries were completed in the late 1970s. However, after the revolution, the relations between the two countries degenerated and the cooperation agreement between the two countries was never signed. During the Iraq-Iran war (1980-1988) Iran's search reactors were bombarded several times. After the war, Iran turned to Russia as a supplier that could complete its nuclear power plant in Bushehr.

In 2002, the existence of two nuclear power plants in Arak and Natanz was revealed and this was the beginning of the ongoing tension between the IAEA, Iran, the European trio, namely Germany, France, and Great Britain, and the United States. Iran insisted that these two plants were for peaceful purposes only, but the U.S. and the West claimed that they were two sites for nuclear weapon program. Since then, Iran has invited the IAEA specialists to visit its nuclear sites and there have been a number of negotiations between Iran and the Western sides of the conflict. Although no evidence has been found for producing nuclear weapons, Iran has faced many economic sanctions and military boycotts. In 2006, the stand-off between Iran and the West extraordinarily increased after the ex-President of Iran made some confrontational remarks against Israel and the West while the country re-opened its nuclear enrichment facilities. In 2010, the U.S. threatened to attack Iran when Iran announced that it planned to build 10 research reactors for medical purposes (World Nuclear Association, 2010).

This tension has continued until now and has attracted world attention. Hence, a number of studies using a CDA framework have recently focused on Iran's nuclear program (e.g. Izadi and Saghaye-Biria, 2007; Atai and Adriani, 2009; Rasti and Sharagard, 2012). To the best of our knowledge, this study is among the few studies which analyzed the discourse of the two sides of the debate. Most of the studies done on Iran's nuclear program have taken a conservative position and have focused only on the discourse of American newspapers. Therefore, this study aimed to investigate the discourse of both sides of the debate on the representation of Iran's nuclear program. Thus, it can bridge the gap in the literature.

\section{MethodolOGY}

\section{A. Sources of Data}

The sources of data for this study were two newspapers: The Los Angeles Times and Tehran Times. The reports which were written on Iran's nuclear program were collected from the websites of these newspapers. The main reason for the selection of these newspapers is that these newspapers belong to the countries that are the two main opposing sides of Iran's nuclear program. Another reason is that The Los Angeles Times is one of the top American newspapers which has not been attended to in previous studies done on American newspapers and Iran's nuclear program. Tehran Times is also one of the Iranian newspapers in English which is published in Iran and other countries. Moreover, these newspapers can be easily accessed in their websites.

\section{B. Procedures}

In order to have a better comparison of how an event may be presented differently by the two newspapers with different perspectives, the following stages for data collection and sampling were adopted.

A period of 37 days, from May 15 to June 21 in 2010, was selected to collect news reports relating to Iran's nuclear issues from The Los Angeles Times and Tehran Times websites. This period of time was selected since two important 
events occurred during this period: one is the signing of a deal by Iran, Turkey, and Brazil on May 17 and the other is the fourth round of sanctions endorsed against Iran by the UN on June 9. During this period, 40 news reports from The Los Angeles Times, and 90 news reports from Tehran Times were collected. All these news reports dealt with issues relating to Iran's nuclear program.Then, out of these collected news reports, the researchers decided to find subjects relating to Iran's nuclear program, about which both of the newspapers published some news reports. In order to find these shared subjects, all the headlines of the collected data were carefully studied. Having done this, the researchers found three shared subjects between the two newspapers in the data and the size of the data was reduced to 14 news reports. These three subjects along with the number of the news reports that The Los Angeles Times and Tehran Times published for each of these subjects are presented in Table 1.

TABLE I.

THE SHARED SUBJECTS PUBLISHED IN THE TWO NEWSPAPERS AND THEIR FREQUENCY OF THE NEWS REPORTS FOR EACH SUBJECT

\begin{tabular}{|c|c|c|c|}
\hline \multicolumn{2}{|c|}{ Shared Subjects } & $\begin{array}{l}\text { Tehran } \\
\text { Times }\end{array}$ & $\begin{array}{l}\text { Los } \\
\text { Angeles } \\
\text { Times }\end{array}$ \\
\hline 1 & The sign of a deal by Iran, Turkey, and Brazil on May 17, 2010 & 4 & 2 \\
\hline 2 & $\begin{array}{l}\text { The reaction of Russia after a speech by Iran's president on May } \\
26,2010\end{array}$ & 1 & 1 \\
\hline 3 & The fourth round of sanctions against Iran on June 9,2010 & 2 & 4 \\
\hline \multirow{2}{*}{\multicolumn{2}{|c|}{ Total }} & 7 & 7 \\
\hline & & \multicolumn{2}{|l|}{14} \\
\hline
\end{tabular}

At the end, for each of these three subjects one report per newspaper was randomly selected. As a result, three pairs of news reports with the same subjects were obtained. After taking these procedures for sampling the data, the three pairs of news reports were comparatively analyzed according to van Dijk's (2000) framework to see how Iran's nuclear issues are presented in the two newspapers.

\section{Methodological Framework}

In this research van Dijk's (2000) framework is opted for as the basis of the analyses. This framework is based on an ideological square which presents a general and practical strategy of ideological analysis, and thus can be applied to the analysis of ideological discourse at all levels of discourse. This ideological square has these four principles: "Emphasize positive things about US. Emphasize negative things about Them. De-emphasize negative things about Us. Deemphasize positive things about Them" (van Dijk, 2000, p.44).

The semantic macro-strategies of positive self-presentation employed either for individual face keeping or for collective purposes by focusing on the positive aspects of one's group, and negative other-presentation which is related to the use of derogatory terms and focusing on the negative characteristics of out-group members (van Dijk, 2000) are the bases of this framework. These two macro-strategies are realized by other forty discursive strategies which are potentially possible to occur in different kinds of ideological discourses. However, using this framework in a study, one cannot expect that all these forty strategies to be found in the discourses to be analyzed. Taking this point into account, this framework was used as the basis of the analyses, to find how ideological differences are manifested in the discourse of the two newspapers by the use of the two macro-strategies, in general, and other available strategies in this framework, in particular. The most common discusive strategies of this framework found in the news reports in this study along with descriptions according to van Dijk (2000) are listed here.

Consensus: This is a political strategy which is used especially when a county is threatened by out-groups, so crossparty and national consensus is used.

Hyperbole: A device for the enhancement of meaning, either for positive self-presentation or negative otherpresentation.

Disclaimer: This strategy is used to keep face by stating our positive characteristics first, and then focus on their negative attributes.

Distancing: A socio-cognitive device which may, for instance, be employed by the use of demonstrative pronouns instead of naming or describing Others.

History as lesson: Sometimes a situation is compared to positive or negative events in history, either as a positive self-presentation or negative other-presentation strategy.

Humanitarianism: Invitation of the readers/ listeners to pay more attention to human rights, or show empathy for the situation of in-group members.

Implication: A piece of information may be left implicit because it may be inconsistent with the overall strategy of positive self-presentation. Negative details about in-groups' actions thus tend to remain implicit.

Illegality: A device by which the out-group members are characterized as criminal or law breaker.

National self-glorification: A strategy which is used by referring to the honorable history of one's country, or by praising its principles and traditions.

Presupposition: Van Dijk compares discourses to icebergs, in the sense that most of the meanings of a text are not explicitly expressed but presupposed to be known by the recipients. Presuppositions are used typically to speak about the controversial ideas or to assume the truth of some preposition when such truth is not accepted at all. 
Vagueness: Speakers/writers may make use of vague expressions like: 'few', 'a lot', 'very', 'thing', 'low', and 'high' in order not to give enough information to the readers/ listeners either as a positive self-presentation or a negative otherpresentation.

\section{CDA ANALYSIS OF THE NEWS REPORTS AND DISCUSSION}

In this part, the three pairs of news reports with the same subjects are critically analyzed. Due to the lengthy results of the analyses, only some of the strategies detected in the news reports are presented.

\section{A. A Deal Signed by Iran, Turkey, and Brazil on May 17, 2010}

The first pair of news reports analyzed here is about a deal signed by Iran, Turkey, and Brazil on May 17, 2010 according to which Iran would ship 1200 kilograms of its low enriched uranium for 120 kilograms of 20 percent enriched nuclear fuel rods to power the Tehran research reactor.

In paragraph 13 of Tehran Times' report ("Iran, Turkey, Brazil," 2010), this deal is described as a constructive move: "The Brazilian and Turkish foreign ministers called the deal a constructive move that leaves no pretext for any country or organization to put pressure on Iran". Moreover, in paragraph 15, Tehran Times claims that: "Davutoglu called the agreement 'a great success' which proved diplomacy could still work".

These descriptions of the deal in this way are examples of hyperbole that is a semantic rhetorical device to exaggerate one's act according to one's ideologies and interests. Here, Tehran Times is exaggerating the deal, especially when it is called "a great success", since later on it proved not to be that much of a success. This use of hyperbole is more generally working toward the overall semantic strategy of positive self-presentation. Into the bargain, in paragraph 15 of this report, there is a point about the use of quotation which is worth mentioning. In this sentence, it is not clear whether the second part of the sentence beginning with "which" is told by Davutoglu or is the opinion of the writer injected in the sentence. More possibly, it is strategically added to the previous part to imply that this part is also told by the foreign minister.

Quite to the contrary of Tehran Times, The Los Angeles Times begins its report (Richter \& Parsons, 2010) with expressing the skepticism and indifference on the part of the US officials toward this deal, devoting ten paragraphs to the opinions of the American officials about this deal which are mostly negative. These ten paragraphs imply the American officials' willingness to impose further sanctions against Iran since this deal is not enough for solving larger issues related to Iran's nuclear program. Then from paragraph eleven, The Los Angeles Times begins to give some information to the readers about the content of this deal. This way of presenting the information to the reader is highly ideological. Van Dijk (2000, p.55) states that "sentences that express positive meanings about us, and negative meanings about them, will typically appear up front, if possible in headlines, leads, abstracts, announcements or initial summaries of stories".

In paragraph 5 of The Los Angeles Times' report: “Although it would be a 'positive step' for Iran to transfer lowenriched uranium out of the country, as it first agreed to do last October, Gibbs said, the plan outlined Monday would not resolve long-standing problems", it is first acknowledged that "this deal would be a positive step", then by referring to the last October's deal which was suggested by the US and rejected by Iran, it is mentioned that this plan is not enough to solve long-standing problems. This is an example of the use of a disclaimer (Apparent Concession) in the discourse. This strategy is a combination of the overall semantic strategies of positive self-presentation and negative other-presentation. It is used to save face by first stating the writer's good will and unbiased opinion of Others then focusing on the negative attributes of Others.

Moreover, in paragraphs four, six, eight, and sixteen of this report, Iran is presented as a country that does not "live up to international obligations", a country which tries to develop "a nuclear weapon". The use of this phrase seems to give a horrifying image of Iran which is presented as a threat to human beings. The argumentative strategy used here is called illegality which is an argumentative strategy by the use of which the out-group members are presented as law breakers and criminals. It is used as a device for the overall strategy of negative other-presentation.

The Los Angeles Times and Tehran Times opposed each other in presenting this deal to their readers. It was shown that The Los Angeles Times' report presented this deal as an insignificant act by Iran, as a "ploy" to buy time to prevent further sanctions and by using the strategies of illegality and disclaimer as the most frequent strategies that is used in this report, the American newspaper gave a horrifying, negative picture of Iran's nuclear program. On the other hand, in the Iranian newspaper, the picture that is given to the readers is different from that of The Los Angeles Times, since the contract is presented as a "constructive move" and a sign of Iran's "good will" by using strategies of lexicalization, repetition and hyperbole as the most frequent ones. Therefore, the findings of the analyses of these reports support van Dijk's (2000) notions in his ideological square that in ideologically loaded discourses the focus is on the negative acts of Others and the positive acts of Us.

\section{B. Russia's Reaction toward Iran's Ex-president's Speech on May 26, 2010}

The second pair of news reports is related to Russia's reaction after a speech delivered by Iran's ex-President on May 26, 2010. In this speech, he criticized Russia for siding with the U.S. and adopting negative stances toward Tehran's declaration which was signed by Iran, Brazil, and Turkey on May17. As mentioned in the previous part, according to 
this declaration, Iran was called for to ship 1200 kilograms of its low-enriched uranium to Turkey to be exchanged for 120 kilograms of 20 percent enriched nuclear fuel. Iran considered this deal as "a constructive movement"; however, America and other permanent members of the UN Security Council did not consider this as an influential step and insisted on the imposition of further sanctions against Iran. Russia also sided with this stance of the UN Security Council which made Iran's ex-President to deliver a speech criticizing Russia for its stance toward this movement. Both of the American and Iranian newspapers published reports on the reaction of Russia toward this speech.

Tehran Times chooses this lead paragraph for its article ("Russia supports,"2010) to report on this event:

On day after President Ahmadinejad severely criticized Russia for siding with the U.S. on the Tehran nuclear agreement, two top Russians (sic) officials announced that the Kremlin is ready to support the nuclear fuel swap deal signed between Iran, Turkey and Brazil.

Tehran Times begins the lead with: "On day after President...", to imply that the speech which was delivered by Iran's ex- President was so influential and impressing that just one day after the speech, Russian officials changed their stance toward the deal and announced their readiness "to support" the deal.

Reading this report critically, one can observe that all the lexical choices which describe Russia's reaction toward Iran are positive, conveying a sense of support and friendship and there is not even one word to convey a sense of disagreement on the part of Russia. Ready, backs, support, energetically, contribute, positive, friendly relations, peaceful resolution, actively support, and assist are the words which are repeated throughout this report:

Lead) ... the Kremlin is ready to support the nuclear fuel swap deal signed between Iran, Turkey and Brazil.

2) Patrushev said his country backs nuclear swap on the Turkish territory.

3) Moscow is ready to energetically contribute to a settlement of the problem concerning the Tehran declaration, the Voice of Russia quoted Patrushev as saying.

4) Patrushev also said that Russia believes the outlook for Tehran-Moscow cooperation is positive.

5) For his part, Jalili said, "The Tehran declaration is a positive step for interaction that should be complemented by other side's positive steps."

6) He went on to say that Iran and Russia's common interests and threats necessitate the two nations to maintain friendly relations.

7) ...Lavrov said the Tehran agreement may see a peaceful resolution to the nuclear standoff between Iran and the west.

8) “The scheme (on uranium swap) meets the requirements for a peaceful resolution of Iran's nuclear issue...

On the other hand, The Los Angeles Times' report (Stark, 2010) begins with this headline for its report: "Russia lashes out at Iran". The verb "lashes out" used in this headline to mean: "to criticize somebody in an angry way" (Hornby, 2004), connotes anger and impatience, and by this lexical choice, this American newspaper wants to convey that Russia is so angry at Iran that cannot tolerate Iran's acts any more. This lexical choice works toward negative other-presentation. The lead paragraph also contains negative and derogatory terms when speaking about Iran and when describing the reaction of Russia toward the speech. Moreover, there is a sense of illegality in this lead about Iran which refuses to deal with its nuclear problems: "Foreign Minister Sergei Lavrov dismisses Iranian criticism that Russia is susceptible to Western influence and says Tehran has obstinately refused to address about its nuclear program".

In this report, there are many negative and derogatory terms about Iran and its relationship with Russia. This kind of lexicalization by the writer gives a negative image of Iran:

1) ... dismissed criticism from the Iranian president as "emotional", and expressed frustration over what he portrayed as Tehran's obstinate refusal to...

2) ...lashed backed at Iranian President Mahmoud Ahmadinejad, who a day earlier described the Kremlin as a potential enemy...

5) "Iran's response was unsatisfactory, to say the least".

8) The Russian leadership was outraged by his remarks. A Kremlin aide, foreign policy advisor Sergei Prikhodko, on Wednesday accused Ahmadinejad of "political demagoguery."

9) The rhetoric reflects a new depth of Moscow's impatience with Tehran...

12) ..., and criticized Iran for wasting time by rejecting the earlier offer.

In paragraph 12 of this report: "He pointed out that much of the recent agreement was recycled from a proposal made in 2009 by the International Atomic Energy Agency, and criticized Iran for wasting time by rejecting the earlier offer", The Los Angeles Times refers to the deal which was proposed by the International Atomic Energy Agency in October 2009 and rejected by Iran. Here, the strategy of history as lesson is used by referring to this deal. The Los Angeles Times wants to convey that the deal suggested by Iran on May 17 cannot be trusted upon since it is the repetition of that previous one which Iran refused to act upon.

An interesting point about these news reports is the way the two newspapers present the information and the events. The Iranian newspaper focuses on a telephone conversation which was initiated by the Russia's officials at the beginning of the news reports. However, The American Newspaper begins the report with some quotations from Russian officials, all of them conveying a sense of anger and impatience toward Iran in general, and the speech delivered by Iran's ex- President on May 26 in particular. Then, by the use of the sentence : "But it was not all tough talk", nearly at the end of the report, in paragraph 13, The Los Angeles Times changes the tone and begins to mention 
some positive words and phrases about Russia and Iran's relationship. In this part, the American newspaper also refers to the telephone call initiated by the Russian officials to the Iranian officials on Thursday, one day after the Iran's exPresident's speech. This way of ordering the information related to an event in the text is highly ideological, since the writer first focuses on the negative parts related to the Others, and then at the end of the text mentions some minor information about the positive points, as a strategy to emphasize negative things about Them and de-emphasize positive things about Them. This way of presenting the events in discourse is highly ideological. These support Van Dijk (2000) who states that:

Information that is favorable for or about the own group or unfavorable for the out-group will tend to be topical, important and explicit. Information that portrays us in a negative light will tend to remain implicit, not topicalized, hidden, vague and little detailed (p.78).

\section{The Fourth Round of Sanctions against Iran}

The third subject related to Iran's nuclear program which attracted the attention of The Los Angeles Times and Tehran Times is the fourth round of sanctions approved against Iran. In spite of Iran, Turkey, and Brazil's efforts to prevent this round of sanctions such as signing a deal on May 17, 2010 to deliver much of Iran's low-enriched uranium to Turkey, the U. S. and its allies were the winners and the United Nations Security Council approved another round of sanctions against Iran for its development of nuclear program on June 9, 2010. However, this round of sanctions was not considered by the U.S. and its allies that much of a victory since they could not satisfy Turkey and Brazil to vote in favor of the sanctions and these countries voted against the sanctions and Lebanon abstained.

Tehran Times selects lead paragraph for its report ("Iran Dismisses," 2010): "In response to the UN Security Council's ratification of a fourth sanctions resolution against Iran, Iran's ex-President said that Iran will itself produce the 20 percent enriched uranium to power the Tehran research reactor". Instead of reporting about the details of the resolution, this lead is selected to show that Iran does not care about these sanctions and that in spite of all the pressures imposed by the U. S. and its allies, it has yet the power to produce $20 \%$ enriched uranium by itself.

Taking a cursory look at this report, it becomes obvious that this report is composed of several Iranian officials' quotations, containing derogatory and negative terms about the U.S, the Security Council, and the resolution. The exPresident of Iran is voiced more than other officials (he is quoted twelve times). Moreover, all the quotations mentioned in this report convey a sense of anger, warning, indifference toward the sanctions, and manifestation of power.

By the use of a derogatory term: "a worthless scrap of paper", in paragraph 2 of this report: “... Ahmadinejad called the UN resolution 'a worthless scrap of paper' "; the Iranian newspaper aims to have a negative other-presentation and to imply that the approved sanctions against Iran are not important in the view of Iranian officials.

In paragraph 20 of this report: "On Wednesday, Iran's ambassador to the UN said, "No amount of pressure and mischief will be able to break our nation's determination to pursue and defend its legal and inalienable rights", by mentioning "our nation determination", Tehran Times is using a consensus strategy to show that all the Iranians are supportive of the nuclear program which is obviously a presupposition. Moreover, in paragraph 20: the argumentative strategy of legality is used by the phrase: "its legal and inalienable rights".

In paragraph 21, Tehran Times quotes from Iran's ambassador:

Ambassador Mohammad Khazaee added, "Iran is one of the most powerful and stable countries in the region and never bowed -- and will never bow -- to the hostile actions and pressures by these few powers and will continue to defend its rights."

Here a presupposition is used. One can ask whether Iran is really one of the most stable countries in the region, or it is strategically presupposed as a positive self-presentation. Another strategy which is used here is national glorification. Iran is described as a powerful country in spite of all the pressures and sanctions which have been imposed on it by the western powers during the history. The use of "few" is also strategically used here. Are they really few? In the UN Security Council, twelve members supported the imposition of this latest round of sanctions against Iran and the fact is that the countries against Iran are not few at all. Into the bargain, the actions of these powers, which are presupposed here to be few, are described as "hostile", a derogatory term opted for to convey that what these powers do, such as the imposition of sanctions against Iran, are based on their hostility against Iran , not because of justified or defensible reasons. Moreover, the strategy of legality is repeated here by the use of the words: "...defend its rights".

In contrast to Tehran Times' report which chose to begin its report with the announcement of a new decision about the production of 20 percent enriched uranium by itself as a reaction toward the resolution, The Los Angeles Times' report headlined: "U.N. adopts new sanctions against Iran" begins its report (Richter, 2010) with this lead:

In a diplomatic setback, the U.S. fails to win unanimous support for latest round of sanctions approved by the U.N. Security Council. Turkey and Brazil voted against the sanctions meant to punish Iran for its nuclear program, and Lebanon abstained.

The lead of this report begins with "in a diplomatic setback" as the theme of the sentence, accompanied with the verb "fail". These lexical choices are made to give a picture of dissatisfaction of the results of the resolution on June 9. The American newspaper wants to imply that although the sanctions were approved by the UN Security Council, it was not a victory for the U.S. since Turkey and Brazil voted against the sanctions. The U. S. ultimate goal had been to have a unanimous support from all the members to be able to punish Iran. The word punish is also a derogatory term. Generally, from the CDA point of view, the description of this absence of unanimity as "a diplomatic setback" and a 
failure is a kind of irony. Iran is described as a country that has done illegal and even dangerous activities especially in its development of nuclear energy and it is needed that all countries be united in halting this country from these activities. Now that two countries have voted against this resolution, The Los Angeles Times describes this event as a failure for the U.S.

In paragraph 3: "Iran insists the nuclear program is intended for development of civilian energy, but the U.S. officials and many world leaders charge Iran is seeking an atomic weapon capability", the use of "U.S. officials and many world leaders" is a kind of consensus strategy to convey that most of the world is against Iran and that U. S. is not alone in its opposition against Iran. Moreover, by the use of "atomic weapon capability" in this sentence, the discursive strategy of illegality is used. By the use of this strategy, Iran is presented as a dangerous law breaker which is seeking to produce atomic weapons and because of this, all the world is needed to cooperate with the U.S to prevent from a catastrophe for human begins. These two strategies used in this paragraph work to give a negative image of Iran.

In Tehran Times' report, the most frequent strategy is lexicalization; all of the lexical choices are derogatory and negative. The justification of this finding can be that, this report intends to show the anger of the Iranian officials about this round of sanctions and by using derogatory terms this newspaper tries to undermine the imposition of these sanctions and also the validity of the UN Security Council. The Los Angeles Times' report was also found to be full of discursive strategies most of which work toward negative other-presentation, giving a horrific image of Iran's nuclear program. Using strategies such as illegality, the writer tried to justify the imposition of this round of sanctions by the USA and its allies. The findings of these two news reports' analyses confirm van Dijk's (2000) claim that "ideologies impinge on discourse" (p.82).

\section{CONCLUSIONS}

The results obtained from the CDA analyses of the three pairs of news reports showed that ideological manipulations of language can be exercised by the use of the two overall semantic macro-strategies of van Dijk's (2000) framework: positive self-presentation and negative other-presentation which are realized by other discursive strategies within this framework. In this study, the most frequent strategies which were used by the two newspapers to realize these two macro-strategies are: lexicalization, presupposition, consensus, hyperbole, illegality and disclaimer.

The findings also manifested that The Los Angeles Times and Tehran Times represented the issues related to Iran's nuclear program differently, according to their points of view and perspectives. The analyses showed that the three subjects which were focused on, in this study, were presented differently in the two American and Iranian newspapers. Among the three pairs of news reports, the second pair relating to Russia's reaction toward Iran's ex-President's speech was found to be highly ideological since the news reports in this pair represented the same subject, namely the reaction of Russia toward Iran after Iran's ex- President's speech on May 26, 2010. The writers of these reports manipulated the language when quoting Russian officials and played with the discourse forms. For example, The Los Angeles Times did not refer to the telephone calls which were initiated by the Russian official until the end of the news report, in an attempt to give a negative image of Russia's relationship with Iran. Tehran Times, on the other hand, focused on this event at the beginning of the report, trying to show the willingness of the Russian officials in negotiating with Iran.

Moreover, the findings of this study corroborate with the findings of Ghiasian (2006), KhosraviNik (2008, 2009, 2010), Atai and Adriani (2009), and Yaghoobi (2009), among many other studies conducted within CDA frameworks, about the biased representation of events and social groups in newspapers. Moreover, the findings lend supports to van Dijk's (2000) belief that "discourses express, confirm, instantiate or constitute ideologies" (p. 86), and to the fact that ideologies are injected in discourse by the use of different kinds of discursive strategies like the ones which are included in van Dijk's (2000) framework. As such, the findings of this study call attention to the importance of being aware of the potentiality of language to manipulate the facts and realities.

Into the bargain, the results of this research prove the efficiency and conclusiveness of van Dijk's (2000) framework in the uncovering of hidden ideologies in discourse. Accordingly, the findings of this study being based on van Dijk's (2000) semantic discursive categories can enrich the CDA literature, since the study is among few CDA studies which focus on semantic categories, not the syntactic structures of discourse as have been attended to many other CDA studies (e.g. Hernandez, 2008 and Yaghoobi, 2009).

\section{IMPLiCATIONS FOR LANGUAGE PEDAGOGY}

This study has a wake-up call for students to be aware of the power of language in changing and even making their points of view and opinions about the events, the people, and the world around them. This awareness of the power of language in inculcation of ideologies is highly vital for EFL learners since they are exposed to a variety of authentic materials such as textbooks and movies which are produced by the native speakers of English. As such, EFL learners can "act as transmitters of foreign thoughts and beliefs to their own culture" (Koupaee, 2010, p.1). Therefore, EFL learners should be aware of the possible latent meanings that are injected in these materials, to resist the imposition of ideologies on them.

The findings of this research and the CDA analyses of the news reports can also be insightful in the courses that deal with journalism and reading comprehension. EFL teachers of these courses can introduce the CDA framework 
introduced in this study to their students and ask them to critically analyze the news and texts they read in class or in their daily life. By doing this, the teachers help EFL learners to be equipped with some analytical tools to detect the hidden meanings in the discourse they deal with and improve their reading skills, as was proved by (Asgharzadeh, 2009). Moreover, using CDA tools in EFL classes can increase EFL learners' creativity, motivation and activity (Koupaee, 2010).

\section{REFERENCES}

[1] Asgharzadeh, R. (2009). The effect of teaching critical reading through critical discourse analysis on high school EFL learners' reading comprehension. Master's thesis. University of Shiraz, Shiraz, Iran.

[2] Atai, M. R., \& Adriani, H. (2009). On the representation of Iran's post-resolution nuclear issues in American news editorials: A critical discourse analysis. Iranian EFL Journal 5, 20-45.

[3] Bennett, W. L. (1990). Toward a theory of press-state relations. Journal of Communication 40. 2, 103-125.

[4] Entman, R. (1993). Framing: toward clarification of a fractured paradigm. Journal of communication 43.4, 51- 8.

[5] Fairclough, N. (2001). Language and Power (2nd edn.). London and New York: London.

[6] Fowler, R. (1991). Language in the News: Discourse and Ideology in the Press. London: Routledge.

[7] Ghiasian, M. (2006).The representation of Muslims in American and British newspapers before and after Septembet11. Master's thesis. Tarbiat Modarres University, Tehran, Iran.

[8] Hackett, R. A. (2006). Is peace journalism possible? Three frameworks for assessing structure and agency in news media. Conflict \& Communication Online 5. 2, 1-13.

[9] Herman, E. S. (1996). The propaganda model revisited. Monthly Review. http://www.chomsky.info/onchomsky/199607--.htm (accessed 23/5/2011).

[10] Herman. E.S., \& Chomsky, N. (1988). Manufacturing consent: The political economy of the mass media. New York: Pantheon.

[11] Hernandez, A. A. (2008). SFL and CDA: Contributions of the analysis of the transivity system in the study of the discursive construction of national identity (Case study: Gibraltar). Linguistic Journal 3. 3, 160-175.

[12] Hornby, A.S. (2004). Oxford advanced learner's dictionary. London: Oxford University Press.

[13] Iran, Turkey, Brazil agree on nuclear deal. (2010, May 18). Tehran Times. http://www.tehrantimes.com/ (accessed 18/5/2010).

[14] Iran dismisses resolution, announces plan to produce $20 \%$ enriched fuel. (2010, June 12). Tehran Times. http://www.tehrantimes.com/ (accessed 13/6/2010).

[15] Izadi, F., \& Saghaye-Biria, H. (2007). A discourse analysis of elite American newspaper editorials: the case of Iran's nuclear program. Journal of Communication Inquiry 31. 2, 140-165.

[16] KhosraviNik, M. (2008).The British newspapers and the representation of refuges, asylum seekers and immigrants between 1996 and 2006. http://www.ling.lancs.ac.uk/groip/clsl/docs/clc128.pdf. (accessed 13/6/2010).

[17] KhosraviNik, M. (2009). The representation of refugees, asylum seekers and immigrants in British newspapers during the Balkan conflict (1991) and the British general election (2005). Discourse and Society 20. 4, 477-498.

[18] KhosraviNik, M. (2010).The representation of refugees, asylum seekers, and immigrants in British newspapers: A critical discourse analysis. Journal of Language and Politics 9.1, 1-28.

[19] Klaehn, J., \& Mullen, A. (2010). The Herman-Chomsky Propaganda Model: A critical approach to analyzing mass mediabehaviour. Sociology Compass 4. 4, 215-229.

[20] Koupaee, D. Z. (2010). Teaching reading with a critical attitude: Using critical discourse analysis (CDA) to raise EFL university students' critical language awareness (CLA). Master's thesis. University of Kashan, Kashan, Iran.

[21] Rasti, A., \& Sahragard, R. (2012). Actor analysis and action delegitimation of the participants involved in Iran's nuclear power contention: A case study of The Economist. Discourse \& Society 23. 6, 729-748.

[22] Reah, D. (2002). The language of newspapers (2nd edn.). USA: Routledge.

[23] Pedro, J. (2011). The propaganda model in the early $21^{\text {st }}$ century. International Journal of Communication 5, $1865-1905$.

[24] Richter, P., \& Parsons, C. (2010, May 17). New Iran offer doesn't resolve nuclear problem, U.S. says. The Los Angeles Times. http://www.latimes.com/ (accessed 18/5/2010)

[25] Richter, P. (2010, June 9). U.N. adopts new sanctions against Iran. The Los Angeles Times. http://www.latimes.com/ (accessed $13 / 6 / 2010)$.

[26] Russia supports Iran's nuclear fuel pact. (2010, May 29). Tehran Times. http://www.tehrantimes.com/ (accessed 13/6/2010).

[27] Semetko, H., \& Valkenburg, P. (2000). Framing European politics: Content analysis of press and television news. Journal of Communication 50. 2, 93-109.

[28] Shoemaker, P., \& Reese, S. (1996). Mediating the message: Theories of influence on Mass media content. White Plains, NY: Longman.

[29] Stack, M. K. (2010, May 28). Russia lashes out at Iran. http://www.latimes.com/ (accessed 29/5/2010).

[30] Van Dijk, T. A. (2000). Ideology and discourse: A multidisciplinary introduction. http://www.discourses.org (accessed 23/6/2010)

[31] World Nuclear Association (2010). Nuclear power in Iran. http://www.world nuclear.org/info/infl19_nuclearian.html (accessed 23/7/2010).

[32] Yaghoobi, M. (2009). A critical discourse analysis of the selected Iranian and American printed media on the representations of Hizbullah-Israel war. Journal of Intercultural Communication 21, 124-15.

Moussa Ahmadian is an associate professor of Department of English Language and Literature, at Arak University, Iran. His fields of interest are Psycholinguistics and Instructed SLA, TEFL, Critical Discourse Analysis, Translation Studies and Literature, on which he has published and presented a number of papers in inter/national journals and conferences. He has also carried out a number 
of research projects most of them on Translatology (the psycholinguistic aspects of translation), texology (text analysis) and translation. He has supervised more than 40 M.A. theses in the fields of (applied) Linguistics, Second Language Acquisition and teaching, Translation and English Literature.

Elham Farahani has an M.A. in TEFL from Arak University, Iran. She is currently a visiting lecturer in the Department of English Language at Mofid University, Iran. Her fields of interest include: CDA, discourse analysis, corpus linguistics, EAP, and second language writing. She has published and presented a number of papers in international journals and conferences on critical discourse analysis and ELT. 